ISSN1027-5495. Functional Materials, 23, No.4 (2016), p. 587-591

doi:https://doi.org/10.15407/fm23.04.587

(C) 2016 - STC "Institute for Single Crystals"

\title{
Experimental study on tribological property of mechanical seals with changeable pore diameter
}

\author{
Ma Chenbo, Duanyanjun and Sun Jianjun \\ School of Mechanical and Electrical Engineering, Nanjing Forestry \\ University, Nanjing, Jiangsu, 210037, P.R. China
}

Received August 18, 2016

\begin{abstract}
To study tribological property of mechanical seals when distributing micropores along the radial face with changeable parameter, friction experiments of mechanical seals under a certain condition were carried out while the pore diameter changed. The results show that: the introduction of micropores on the surface can reduce the friction efficiently, but its antifriction effect is closely related to the distribution of micropores. The friction coefficient is the smallest when pore diameters increasing by degrees along the seal radial face from the inside out, while complexly distributed of pore diameter has a poor effect on antifriction of mechanical seals. The results can offer some help for optimal design of mechanical seals with micropores.
\end{abstract}

Keywords: Mechanical seals, changeable pore diameter, antifriction, experimental study.

\begin{abstract}
Проведены исследования трибологических характеристик механических уплотнений в зависимости от размера и распределения пор вдоль радиуса уплотнителя. Результаты показывают, что введение микропор на поверхность уплотнителя может уменьшить трение. Показано, что антифрикционный эффект также тесно связан с распределением микропор на уплотнителе. Коэффициент трения является наименьшим, когда диаметр пор увеличивается постепенно вдоль радиуса уплотнителя от центра наружу, в то время как распределение пор по размеру вдоль радиуса уплотнителя мало влияет на его антифрикционные механические свойства. Результаты могут быть использованы для оптимального проектирования механических уплотнений с микропорами.
\end{abstract}

Експериментальне дослідження трибологічних характеристик механічних ущільнень з різним діаметром пор. Ма Ченбо, Гу Вейфенг, Ма Ченгбін

Проведено дослідження трибологічних характеристик механічних ущільнень в залежності від розміру і розподілу пір вздовж радіуса ущільнювача. Результати показують, що введення мікропор на поверхню ущільнювача може зменшити тертя. Показано, що антифрикційний ефект також тісно пов'язаний 3 розподілом мікропор ущільнювач. Коефіціент тертя е найменшим, коли діаметр пір збільшуеться поступово уздовж радіуса ущільнювача від центру назовні, в той час як розподіл пор за розміром вздовж радіуса ущільнювача мало впливає на його антифрикційні механічні властивості. Результати можуть бути використані для оптимального проектування механічних ущільнень з мікропорами.

\section{Introduction}

Mechanical seals with micropores are defined as processed micron-sized micropores with a certain shapes, distributions on the surface of the seals, whose original model was set up by Etsion in 1996 [1]. Because of having good lubrication and sealing performance $[2,3]$, simple structure, cheaper price, and convenient to change the shape of micropores, it provides a new choice for people to search for high cost-effective mechanical seals. And schol- 
ars at home and abroad have done a whole bunch of studies systematically on steady-state performance, dynamic performance [4] and the critical open performance [5] of mechanical seals with micropores to investigate the influence of structure, distribution and geometric parameters of micropores in recent years. Among them, in the research of micropores distribution, Hoppermann [6] compared the tribological property when micropores on both sides of the seal surface with those only on one side of the surface. To increase the static pressure effect of micropores on mechanical seals, Etsion $[7,8]$ put forward the thought of seal faces with partial micropores, which are proved to have higher carrying capacity than that when micropores distributed on the whole surface. Zhao [9], Liu [9] and Wu [10] analyzed the sealing property when distributing micropores along the circumference and radius direction in discontinuous sector, straight row fan and helical line. Bai and Bo [12-14] proposed the thought of distributing single or double directional oval micropores and discussed their dynamic pressure effects.

From the available literature, the studies of mechanical seals at present are all carried out on the basis that micropores distributed on the seal faces are evenly and the same size in radial direction. Considering the situation that it has different circumferential velocities, sealing clearances under synergistic effect of heat-stress and boundary conditions in different positions, and the optimal value of pore parameters should match with those differences above, so the optimal value of pore parameters should be changeable along the face.

Thus, this paper did some experimental research on the friction property of mechanical seals, which have variable pore diameters along their radial seal faces under the same pore depth and density. The mechanism of the mechanical seals with changeable pore diameters was also discussed.

\section{Experimental procedures}

Experiments were carried out on MMU-2 high speed face friction and wear testing machine. The upper and lower samples are mechanical seals rings, and the lower sample was fixed, with outside diameter $63 \mathrm{~mm}$, inside diameter $50 \mathrm{~mm}$, material hard alloys YG8, roughness of the surface $R=0.02 \mu \mathrm{m}$. While the rotating upper one was driven by stepper motor, with outside diameter $61 \mathrm{~mm}$, inside diameter $53 \mathrm{~mm}$, material graphitic carbon M106K, roughness of the surface $R_{\mathrm{a}}=0.03 \mu \mathrm{m}$.

The micropores were fabricated on the surface of the upper sample by laser marking ma-

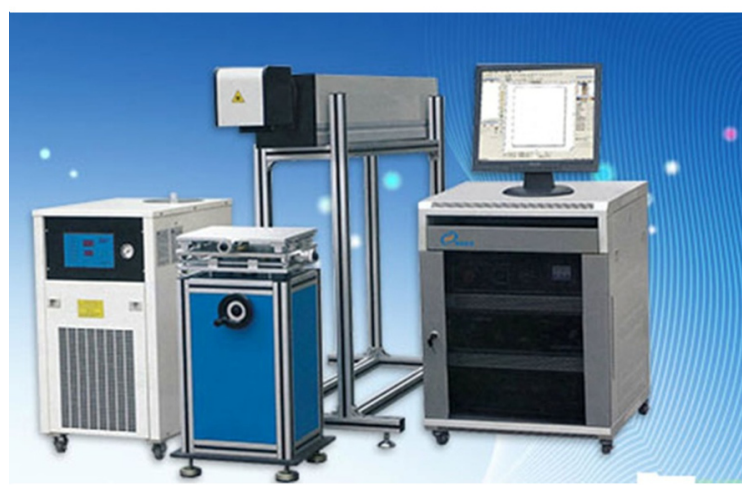

Fig. 1. The laser marking machine using in the processing of pores on seal surface.

chine (as shown in Fig.1) under the conditions that current is $10 \mathrm{~A}$ and frequency is $4 \mathrm{KHZ}$. The pore density and depth were controlled unchangeable and to be equal to $20 \%$ and $4 \mu \mathrm{m}$, respectively. The pore density $S_{\mathrm{p}}$ is defined as the area ratio of pores and the face seals, which can be written as

$$
S_{\mathrm{p}}=\frac{\sum_{i=1}^{n} d_{i}^{2}}{4\left(r_{o}^{2}-r_{i}^{2}\right)}
$$

where,

$d_{i}$ - the pore diameter on the seal surfaces, $\mathrm{m}$; $n$ - the number of pores on the seal surfaces;

$r_{\mathrm{o}}$ - the radius of outer surface for mechanical seals, m;

$r_{\mathrm{i}}$ - the radius of inner surface for mechanical seals, $\mathrm{m}$.

The value of the pore depth was controlled by the amount of laser-machining loops under the given laser parameters. Table 1 listed the relationship between the pore depth and the amount of laser-machining loops, and three laser-machining loops were selected to obtain the pore with the depth of $4 \mu \mathrm{m}$.

While the pore diameters along the seal face in radial were not distributed uniformly, the distribution types of which were shown in Table 2.The mechanical seals without micropores on surface (type 9 in Table 2) were taken as a reference. As shown in Table 1, there are 4 fundamental types of pore diameter distribu-

Table 1. The values of pore depth under different laser-machining loops

\begin{tabular}{|c|c|}
\hline $\begin{array}{c}\text { Amount of } \\
\text { laser-machining loops }\end{array}$ & Pore depth/ $\mathrm{mm}$ \\
\hline 1 & $1.0-1.5$ \\
\hline 2 & $2.0-2.5$ \\
\hline 3 & $3.0-4.0$ \\
\hline 4 & $4.5-5.5$ \\
\hline 5 & $6.5-7.5$ \\
\hline
\end{tabular}




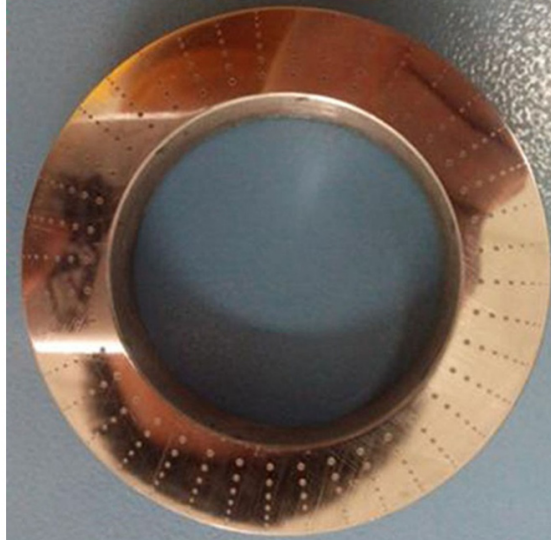

Fig. 2. Specimen of mechanical seals with decreasing diameters along radial of surface.

tion along the face from the inside out named as decreasing, increasing, increasing firstly and then decreasing as well as decreasing firstly and then increasing. And there are two categories for each fundamental type to differentiate variations of pore diameter. The maximum and minimum pore diameters were set as 800 and $200 \mu \mathrm{m}$, respectively. The parameter $\Delta \mathrm{d}$ in Table 2 is defined as the difference of diameters for the adjacent two pores, whose values were 100, 150, 200, $300 \mu \mathrm{m}$, respectively. As an example, Figure 2 showed the picture of fabricated upper sample with the pore diameters decreased gradually in radial face. Figure 3 showed the picture of fabricated upper sample with the pore diameters increased firstly and then decreased gradually in radial face. The polishing process for the surface was conducted

Table 2. Result of experiments and theory

\begin{tabular}{|c|c|c|}
\hline $\begin{array}{c}\text { Type } \\
\text { number }\end{array}$ & $\begin{array}{c}\text { Types of pore } \\
\text { diameter distribution } \\
\text { along the face } \\
\text { (from the inside out) }\end{array}$ & $\begin{array}{c}\text { Variation of pore } \\
\text { diameters/pm }\end{array}$ \\
\hline 1 & Decreasing 1 & $\begin{array}{c}800-200 \\
(\Delta \mathrm{d}=100)\end{array}$ \\
\hline 2 & Decreasing 2 & $\begin{array}{c}800-200 \\
(\Delta \mathrm{d}=150)\end{array}$ \\
\hline 3 & Increasing 1 & $\begin{array}{c}200-800 \\
(\Delta \mathrm{d}=100)\end{array}$ \\
\hline 4 & Increasing 2 & $\begin{array}{c}200-800 \\
(\Delta \mathrm{d}=150)\end{array}$ \\
\hline 5 & $\begin{array}{c}\text { Increasing firstly and } \\
\text { then decreasing } 1\end{array}$ & $\begin{array}{c}200-800-200 \\
(\Delta \mathrm{d}=200)\end{array}$ \\
\hline 6 & $\begin{array}{c}\text { Increasing firstly and } \\
\text { then decreasing } 2\end{array}$ & $\begin{array}{c}200-800-200 \\
(\Delta \mathrm{d}=300)\end{array}$ \\
\hline 7 & $\begin{array}{c}\text { Decreasing firstly } \\
\text { and then increasing } 1\end{array}$ & $\begin{array}{c}800-200-800 \\
(\Delta \mathrm{d}=200)\end{array}$ \\
\hline 8 & $\begin{array}{c}\text { Decreasing firstly } \\
\text { and then increasing } 2\end{array}$ & $\begin{array}{c}800-200-800 \\
(\Delta \mathrm{d}=300)\end{array}$ \\
\hline 9 & Without micropores & -- \\
\hline
\end{tabular}

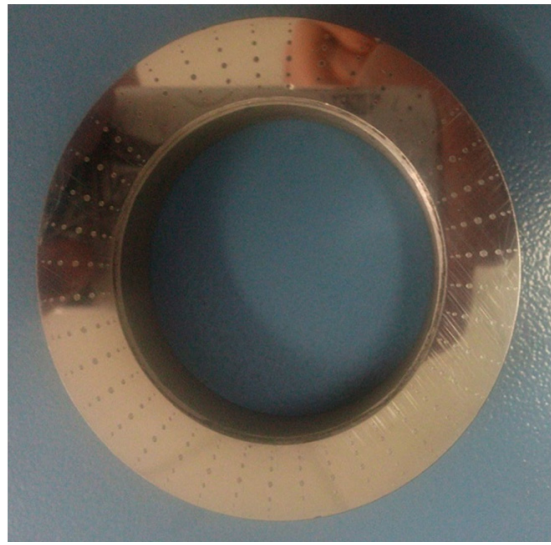

Fig. 3. Specimen of mechanical seals with in creasing and decreasing diameters along radial of surface.

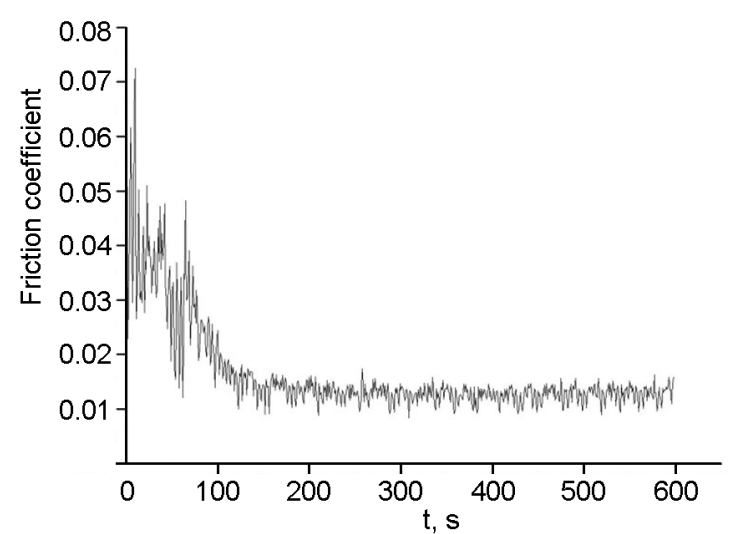

Fig. 4. An example of changing curve of friction coefficient.

after laser fabrication and organic acetone was used to clean the surface.

During the tests, the load $40 \mathrm{~N}$, velocity of upper samples 200 r.min ${ }^{-1}$ and temperature $25^{\circ} \mathrm{C}$ were kept as the constants. Using N32 engine oil as the lubrication oil, whose dynamic viscosity is $31.2 \mathrm{~mm}^{2} \cdot \mathrm{s}^{-1}$ under $40^{\circ} \mathrm{C}$. Friction pairs were soaked in oil to satisfy the condition of full hydrodynamic lubrication. Each tribology test was set to be 10 minutes, and all the

Table 3. Values of friction coefficient under changeable pore diameters

\begin{tabular}{|c|c|}
\hline Type number & Friction coefficient \\
\hline 1 & 0.02296 \\
\hline 2 & 0.01778 \\
\hline 3 & 0.01057 \\
\hline 4 & 0.03827 \\
\hline 5 & 0.03724 \\
\hline 6 & 0.04454 \\
\hline 7 & 0.03798 \\
\hline 8 & 0.03165 \\
\hline 9 & 0.04868 \\
\hline
\end{tabular}


friction pairs were in steady wear state for the time being. The changes of friction coefficient were recorded timely (one record for one second) and more than 3 tests were conducted for each type of friction tests.

\section{Results and discussion}

An example of changing curve of friction coefficient is shown in Fig.4. From Fig.4, the friction coefficient decreasing firstly and flatten gradually, which complies with the general developmental law of friction coefficient.

The average value of friction coefficients of 3 tests with good repeatability was taken as the value of friction coefficient for each type, which was listed in Table.3.

Figure 5 shows the histogram of friction coefficient of mechanical seals under the 9 types in Table 2 with changeable pore diameter. As seen in the figure, the types 1 to 8 that with micropores on the seal face have lower friction coefficient than the type 9 that surface without micropores. This illustrates that the introduction of micropores on surfaces can improve the performance of mechanical seals effectively, which is consistent with the results of precious studies. It is mainly due to the mechanism that each of these micropores can serve as a microhydrodynamic bearing in full lubrication.

From Fig.5, we can also find that the antifriction effects are different for changeable pore diameter along the radial of mechanical seals faces, and some of them make big differences. The friction pairs with biggest or smallest pore diameters in the middle of the seal faces in the radial direction (types 5 to 8 in Table 1) have almost the same friction coefficients, which are all higher than the friction coefficients of mechanical seals with other pore diameter distributions (types 1 to 4 in Table 1). This result shows that increasing the complexity of the pore diameter distribution has a poor effect to reduce friction of mechanical seals. It is mainly because the values of velocity, sealing clearance and boundary condition, which determine the value of the optimal pore parameters, vary monotonically along the radial face. And thus the micropores should distribute with decreasing or increasing diameters along the radial face. That is also the reason why the antifriction effect of types 1 to 4 is better.

By comparing types 1 and 2 with types 3 and 4, we can see that it has a better antifriction effect when the micropores distributed with increasing diameters than decreasing diameters along the radial face. According to the study of Ma [15], the values of pore diameter increase with the increase of velocity when other parameters being held constant. For the

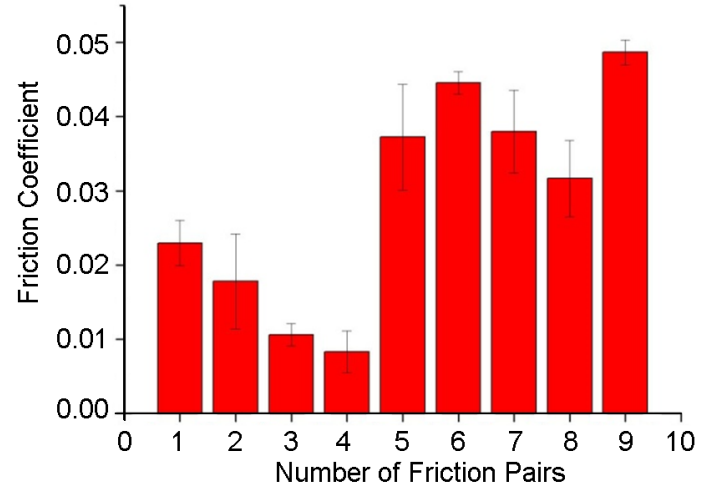

Fig. 5. Histogram of friction coefficient under changeable pore diameters.

mechanical seals ring specimen, due to the peripheral speed increases gradually from inside to outside diameter, the antifriction effect is better when pore diameter in outside is bigger than inside.

Through the analysis of types that with the same pore diameter distribution but different diameter variations (as types 1 and 2, types 3 and 4), it can be seen that the number of micropores along the radial face of mechanical seals has little effect on friction coefficient.

\section{Conclusions}

Experimental study was carried out to investigate the friction property of mechanical seals with changeable pore diameter along the radial face. The conclusions can be summarized as follows:

Distribution of changeable pore diameter along the radial face can reduce friction effectively, but its effect is closely related to the type of distribution.

It has the best antifriction effect when pore diameter increasing from inside out along the radial face of mechanical seals.

It is not a good choice to fabricate complex distribution of micropores along the radial face of mechanical seals to reduce friction.

\section{Acknowledgements}

This work was financially supported by the Foundation Research Project of China (grant Nos. 51375245 and 51505230).

\section{References}

1. I. Etsion and L. Burstein, Tribol. T., . 39, 677, 1996.

2. L. Burstein and D. Ingman, J.Tribol., 121, 927, 1999.

3. Y. Wan and D. S. Xiong, J. Mater. Proc. Techn., vol. 197, pp. 96-100, 2008.

4. MTC Fari, J.Tribol., 123, 205, 2001. 
5. X. D. Peng, S. K. Liang, S. X. Bai, et.al. Lubr. Eng., 35, 1, 2010.

6. A. Hoppermann, M. Kordt, Oelhydraulik und Pneumatik, 46, 1, 2002

7. I. Etsion, G. Halperin, Tribol. T., 45, 430, 2002.

8. P. Y. Song, Z. G. Wang, Lubr. Eng., 33, 36, 2008.

9. Z. Zhao, X. D. Peng, S. E. Sheng, S. X. Bai, J. Y. Li, J.Chem. Ind. Eng. Soc. China, 60, 965, 2009.

10. X. Liu, X. D. Peng, X. K. Meng, et.al., J.Chem. Ind.Eng. Soc.China, 61, 444, 2010.

11. C. H. Wu, X. K. Meng, J. Y. Li, et.al., Lubr. Eng., 35, 39, 2010.
12. S. X. Bai, X. D. Peng, Y. F. Li , S. E. Sheng, Tribol. Lett., 38, 187, 2010.

13. S. X. Bai, X. D. Peng, J. Y. Li, X. K. Meng, Scie. China Techn.Scie., 54,659, 2011.

14. L. Q. Bai, S. X. Bai, X. D. Peng, et.al., Tribology, 31, 97, 2011

15. C. B. Ma, H. Zhu, Tribol. Intern., 44, 987, 2011. 